\title{
SVĚT KARLA HAVLÍČKA \\ Scénář k výstavě Směle kupředu! Svět Karla Havlíčka
}

\author{
Magdaléna Pokorná (Praha)
}

\section{Dětství v Borové}

Havlíčkovo rodiště Borová je malebně umístěné městečko, které vybíhá do kuželovitého svahu, jehož vrchol, na němž stojí kostel sv. Víta, dosahuje $637 \mathrm{~m}$ n. m. Své jméno dostala po borových lesích, které byly pro tyto končiny typické, koneckonců i ve svém znaku má Borová lva, který sekerou podetíná borovici. První zmínka o ní je z roku 1289.

\section{Ten borovský kosteliček}

stoji na vršku,

skrze lesy smutně na mě hleděl:

„Jsi to ty, můj hošku? “

Pode mnou jest tvá kolébka,

já tě viděl křtít,

starému vikáři ministrovat,

pilně se učit.

Táhnout světem na zkušenou, pak s pochodni jit,

naši chase plamenem veselým

na cestu svitit.

(Karel Havlíček: Tyrolské elegie, 1852)

Vztah ke svému rodišti zdůraznil Karel Havlíček už jako mladý tím, že si ke svému jménu Karel připojil právě přídomek Borovský. Jezdíval sem i poté, co se rodina přestěhovala do Německého Brodu - jako chlapec na prázdniny na faru, v roce 1844 při cestě z Ruska do Německého Brodu a v létě 1855 po návratu z Brixenu, kdy si naposledy prošel místa svého dětství.

Rodný dům Karla Havlíčka měl dramatický osud. Dne 23. prosince 1817 koupil Matěj Havlíček 27 sáhů výměry s částí dvora z gruntu č. 68 za 500 zlatých. Následujícího roku tu postavil dům a kupecký krám. Dne 5. ledna 1833 dům prodal. Do dnešní doby se ovšem dům v původní podobě nezachoval. Stal se totiž obětí rozsáhlého požáru, který schvátil téměř celou Borovou dne 18. září 1835. Nový majitel dům brzy vystavěl znovu. Ale i tento dům zničil v roce 1886 požár. Dnes tedy, když je reprodukován „rodný dům“ Karla Havlíčka, jde vlastně o úplně jiný dům, ovšem skrývající jedinou autentickou památku na ten původní, totiž vytesaný monogram „MH“ (Matěj Havlíček) do žulového průčelí, jímž se dnes prochází do druhé místnosti domu.



Obr. 1. Dobová pohlednice rodného domu Karla Havlícka v Borové. Foto: Muzeum Vysočiny Havličkův Brod.

V borovské škole, kam nastoupil Karel Havlíček sotva pětiletý, působil Antonín Línek. Ten se narodil dne 2. června 1792 a jako pomocník prošel několika školami. V roce 1824 se dostal do Borové, kde sloužil po 47 let a 4 měsíce do roku 1871. Učil tedy nejen Karla Havlíčka, ale celé generace borovských dětí číst, psát, počítat a otvíral jim i jinak cesty do světa poznání. Karel Havlíček se se svým respektem k němu svěřil po létech čtenářům České včely, kterou tehdy redigoval: „,Vzpomínám si posud s vrelou vděčností na svého dokonalého učitele na farní škole borovské, p. Ant. Linka, který již po mnoho let tamějši školu s neúnavnou pilností a s príkladnou pedagogickou schopnosti spravuje. "

$\mathrm{V}$ roce 1832 se rodina Havlíčkových přestěhovala do Německého Brodu, kde Karel Havlíček navštěvoval gymnázium. Svou vzpomínku na tato léta vtělil Havlíček do epigramu, věnovaného tehdejšímu řediteli gymnázia Vincenci Doubravovi: ,Výklady kantora Doubravy / snadno chápe hned každý / však, i třebas bez hlavy, / má-li jenom hřbet".

\section{Studia v Praze}

Do pražského bohosloveckého semináře nastoupil Karel Havlíček po absolvování dvouletého filozofického kurzu dne 30. záŕí 1840. Proč se chtěl stát knězem, svěřil své 



Obr. 2a, 2b a 2c. Báseň, kterou Karel Havlíček věnoval svým učitelům Janu Smutkovi a Janu Mařanovi a která vedla k jeho vyloučení ze studia, vyšla tiskem v Praze roku 1841 u Václava Špinky. LA PNP, fond Havlíček Karel.

mamince v dopise ze dne 15. března 1840: „Nemohu být ničím jiným nežli knězem, ke všemu ostatnímu cítím skoro nelibost a odpor; ale knězem chci být s plnou opravdovostí, a proto věrim, že pro tento dobrý úmysl bůh tomu dopreje své milosti, když my lidé tomu můžeme věnovat jen své usilování. A kněz, dělá-li tolik, kolik může, jest věru nejspokojenějši člověk na světě. "

Projevoval se zde jako pilný a mimořádně soustavně se připravující student. Podnětů ke svému duševnímu rozvoji získával Havlíček celou řadu nejen četbou, ale také stykem se spolužáky a později i ve volném přátelském okruhu kolem bolzanovce kněze Františka Schneidra. Našel tu celoživotní př́tele. Patřili mezi ně Jan Klejzar, František Josef Řezáč a František Mudra.

Podmínky studia byly tehdy velmi př́sné a seminární režim Havlíčka silně stísňoval. „Sklon k volné diskusi a nespoutanosti “ Havlíčkovi vyčítali i nadřízení. Po prvním roce studia mu přitižǐla báseň na počest dvou vyučujících „Janů Křtitelư“ - Mařana a Smutka. Mařan interpretoval tento text jako „nebezpečný“, vnímal jej jako „panslavistický“, u zkoušky, kterou Havlíček skládal právě u něj, pak neuspěl, a ze studia byl vyloučen.

Ještě po létech, $\mathrm{v}$ prvním čísle nově založených Národnich novin ze dne 5. dubna 1848 Havlíček připomněl svoji rozčarovanost ze studií: ,,... semeniště Pražské ochladilo tenkrát znamenitě můj zápal [...] udusilo ve mé [sic!] velikou část pravých náboženských citũ, a teprve za několik let po návratu do zdravého božího světa podařilo se mi po mnohých bouřlivých debatách najiti opèt pravou cestu a pravé veslo."

Karel Havlíček přišel na studia do Prahy v době, kdy tu docházelo $\mathrm{k}$ zintenzivnění veřejného národního a kulturního života. To se projevovalo ve formách literární, vědecké a společenské (vlastenecké bály).

„Měl jsem pořádnou chut' jit se tam podívat, ale že nemám frak a nikdo mi jej nechtěl puijčit, nechal jsem toho a odložil to napres rok!" To psal Havlíček rodičům dne
30. ledna 1842 v souvislosti s prvním českým bálem, který proběhl v budově Konviktu nedaleko Betlémského náměstí.

\section{Pobyt v Rusku}

Pro Karla Havlíčka byla cesta do Ruska v letech 1842 až 1844, kam se dostal na základě doporučení Pavla Josefa Šafaříka, podnětná z mnoha důvodů - seznámil se zde s ruskou literaturou a kulturou i s ruskou životní realitou. Kriticky přistupoval $\mathrm{k}$ velikánům ruského romantismu - Alexandru Sergejeviči Puškinovi a Michailu Jurjeviči Lermontovovi. Obdivoval ale Nikolaje Vasiljeviče Gogola, jehož dílo překládal do češtiny. Jeho okouzlení Ruskem a ideou slovanství brzy ustoupilo kritickému vnímání (stat' Slovan a Čech), probudilo u něj i satiricky laděnou tvorbu (epigramy). Jeho tvorba posunula (Obrazy z Rus) výrazně i vnímání Ruska a Slovanstva obecně v celé české společnosti.

Karel Havlíček se do Ruska dostal dne 10. ledna 1843 přes polský Lvov. V Rusku se měl stát domácím vychovatelem v rodině Michaila Petroviče Pogodina. Ten ho však postoupil svému kolegovi Stěpanu Petroviči Ševyrjovovi, profesoru ruské literatury na moskevské univerzitě. Působení $\mathrm{v}$ této rodině poskytovalo Havlíčkovi podmínky pro další aktivity - souvislou četbu, studium cizích jazyků a př́pravu na budoucí literární práci. Zároveň mu zdejší pobyt umožňoval čilý styk s moskevskou intelektuální a společenskou elitou, zaujat byl také výklady o českých dějinách na univerzitě. Díky rodinným vazbám Ševyrjovovy manželky mohl sledovat představení moskevského Velkého divadla př́mo v prestižní lóži a měl patrně i př́stup do tamní bohatě zásobené knihovny. Ovlivnilo jej také to, že mohl poznat poměry na ruském venkově v souvislosti s pobytem Ševyrjovových na jejich letním sídle.

„Aby Kollár jenom mohl príiet do Rus místo mne! On by si zoufal za to, čím sám k tomu slovanstvi dopomáhal! Vám, který jste znal mé smýšlení, než jsem odjel přes hranici, musí být jaksi divno okolo duše, když slyšite tak zpívat 


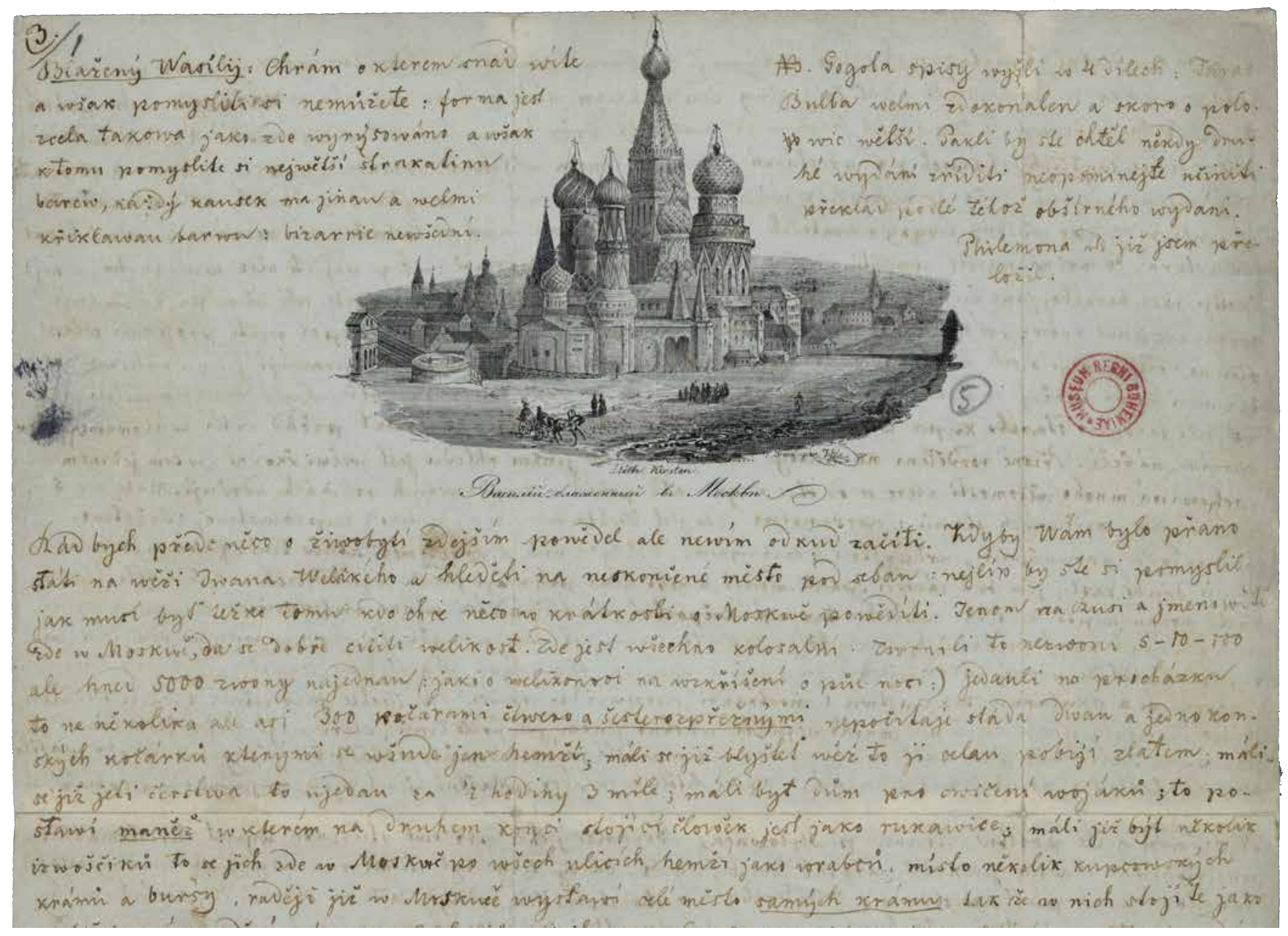

Obr. 3. Havlíčkův dopis z Ruska, ve kterém popisuje krásy Moskvy. LA PNP, fond Havlíček Karel.

z jiného tónu! " psal Karel Havlíček Karlu Vladislavu Zapovi z Moskvy do Lvova dne 30. dubna 1844.

Brzy byl Karel Havlíček celkovými poměry v Rusku zklamán. Příčiny rozkolu mezi Havlíčkem a Ševyrjovem byly několikeré. Jednou z nich byl rozdílný náhled na vychovatelské metody - tradičně bývá zmiňována historka o pohlavku, který Havlíček uštědřil Borisi Ševyrjovovi na oplátku poté, co ten uhodil sluhu. O dva roky později si Ševyrjov v dopise Pogodinovi stěžoval, že Havlíček svým svěřencům málo vštěpoval zásady poslušnosti a lásky $\mathrm{k}$ rodičům. „Přitomnost Havličkovu v mém domé pokládám za skutečné neštěstí, " poznamenal. V rozdílném náhledu na autority se odrážela Havlíčkova vzrůstající nechut' k autokratickým poměrům v ruské společnosti. Při kritice ruského samoděržaví zároveň Havlíček negativně vnímal i slavjanofilství.

\section{Po návratu z Ruska}

Havlíčka sice v Rusku mnohé zklamalo, ale výstavnost Moskvy obdivoval. „, Kdyby bylo možná rozsypat ji, ,kamennou matičku', po celé Evropè, ještě by se z ni dostalo každému městu několik krásných stavení. Tu radost, kterou mivám, kdykoli po ulici jeda na domy se dívám, nemohu nijak ve Vás psaním svým vzbuditi: zostavuji to oustnímu popsání, až se někdy v naší Praze opět po poutěch svých shledáme, “ psal K. V. Zapovi v květnu 1843.
V Rusku se rodily Havlíčkovy literární plány do budoucna. Své spisovatelské ambice tehdy promítal především do oněch „malých nádobek“, jak nazýval epigramy, s nimiž se svěřoval svému příteli Tadeáši Klejzarovi.

Krátce před návratem do Německého Brodu se Havlíček dozvěděl o úmrtí svého otce. Jako jeho nejstarší syn pomáhal matce a horlivě ,vlastencoval“" - na matčin krám nechal vyvěsit česky psaný štít, pořádal českou besedu a založil tu ochotnické divadlo.

„Nehráme zde divadlo an und für sich, jak Němci řikají, ale jen co podřizený účel, aby se čeština vštípila do mysli vyššim třidám našich německobrodských korholtářù [...]. Proto také jsem hledèl, aby herci-ochotníci byli patriciji, jak již podlé holek pozorujete. Co se tedy nedostane velikosti charakterům, to nám jinudy do kapsy naskoči, " psal v dopise př́teli Josefu Šrámkovi.

Pro premiéru v listopadu 1844 zvolil Havlíček Kotzebuovo drama Epigram, jehož hlavní hrdina musí kvůli své břitké satiře opustit rodné město, aby se v nepoznání coby vážený lékař vrátil po několika letech zpět a po překonání několika peripetií získal ruku své milé. V rychlém sledu pak následovaly další hry. Právě při divadelním ochotničení se Havlíček seznámil s Františkou Weidenhoffrovou, dcerou z vážené německobrodské rodiny, a měl v plánu se s ní oženit. Jejich světy se ale rozešly - nevěsta, spjatá se svou rodinou, mohla těžko přijmout hodnoty a priority mladého 




Obr. 4. Reklama na divadelní představení Zmatek nad zmatek Augusta Kotzebua, které se uskutečnilo v Německém Brodě v roce 1844. Foto: Muzeum Vysočiny Havlíčkův Brod.

muže, který se na jaře 1845 vydal do Prahy, kde vstoupil do úplně jiného prostředí, s nímž se ztotožnil a v němž se dokázal prosadit. Oddal se novinářství a službě vlasti.

\section{Novinářem - Pražské noviny}

Karel Havlíček svoji novinářskou kariéru zahájil jako redaktor Pražských novin, kam ho doporučil František Palacký. Pražské noviny vycházely od osmdesátých let 18 . století a až téměř do poloviny 19 . století zůstávaly v českém prostředí jediné. Na vydávání novin od ledna 1846 získal právo na šest let Karel Vilém Medau. Pokud měl vydavatel Medau splnit své smluvní závazky, musely Pražské noviny vydělávat, a aby vydělávaly, musely si získat zájem veřejnosti, přesvědčit publikum, aby je kupovalo a hlavně předplácelo. Vedle ekonomických tlaků musel nový redaktor novin počítat i s cenzurním řízením.

$\mathrm{S}$ radami, jak vést noviny, přispěchal i Havlíčkův přítel Vilém Gabler v dopise ze dne 28. listopadu 1845: „, Le Journal de Francfort a Všeobecné noviny ti podaji skoro všecko, co budeš potřebovat pro tvé artikule; jen bych ti ještě radil, abys hleděl dostat taky die Deutsche allgemeine Zeitung (Leipzig), jenž je v ohledu německé řiše komplementum augsburské. Tak bych myslel, že by bylo nejlépe nic jen opsat z jiných novin, nébrž vždy sám sepsat artikul a neoznámiti novinu, z které je vytažený... Jakožto redaktor politických novin máš tu povinnost ... v hlavě mít dokonalou známost s nynějšim stavem všech věcí v Evropě - to všecko se dozvíš z Rottkova Staats-Lexikon. Gothaský almanach si kup, abys vědèl, kolik a jakých dètí má který potentát a který na kterém dvoru je vyslanec etc. etc. Dobrý zemépis a dobré mapy nebudou zbytečny. Francouzsky bys mél umět, a to nejenom číst a rozumět, nébrž také mluvit, a dobře mluvit. "

První číslo „svých“ Pražských novin otevřel Karel Havlíček 1. ledna 1846 osobním vyznáním: „Vždy bývala nejvrelejši moje touha, abych co spisovatel přispéti mohl poněkud k zvelebení vlasti své a k poučení i k vyražení svých krajanů. " Havlíček jako redaktor prokázal, že je dobře připravený. Hned v prvních dnech svého působení v redakci

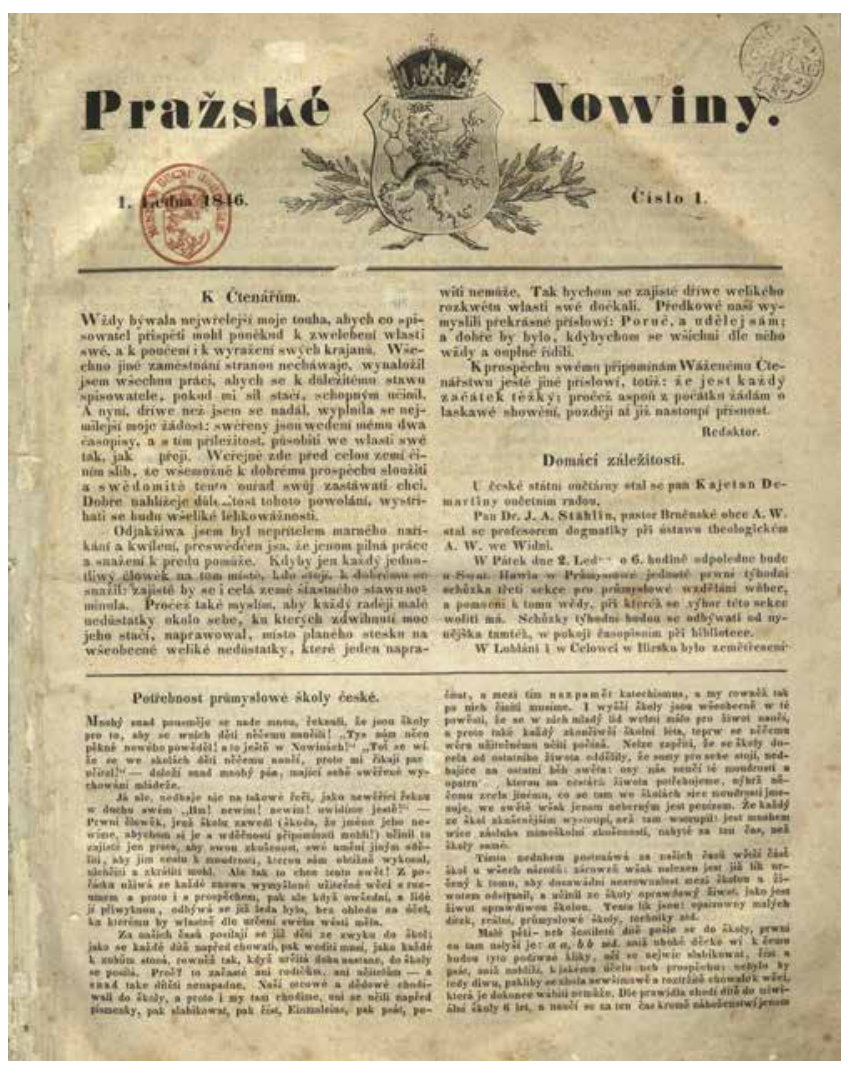

Obr. 5. Vydání Pražských novin v redakci Karla Havlíčka ze dne 1. ledna 1846. Foto: Knihovna Národního muzea.

otevřel téma průmyslové školy pro českou mládež v článku Potřebnost průmyslové školy české. Téma školství neopustil ani později. V dalších číslech otiskl svůj programový text Slovan a Čech, jímž otřásl dlouholetými představami české společnosti o slovanské vzájemnosti a znovu rozbouřil veřejné mínění. Programový charakter měla také stat' $C o$ jest obec?, tištěná na deset pokračování koncem roku 1846: „,Obec je zř́izena $k$ prospěchu všech, ne jednotlivce, a aby správně fungovala, musí v ní žit poučeni lidé. Každému z nás budou následky té nevědomosti známy ze zkušenosti. Jak často vidíme muže jinák v privátním životě svědomité, kteři by žádným zpưsobem nikoho ze sousedì svých ani o nejmenši věc neošidili, proti státu jednati lstivě a velmi ošemetně. Patřme na veřejné stavby, na silnice, železnice, na pachty, odvody k veřejným zemským potřebám a vi̊bec na všechno, co obec na své útraty koná, jaké se tu často dějí podvody! "

Jiným Havlíčkovým zásadním článkem byla stat' Daniel O'Connell, která vycházela v červnu 1847 . Vylíčil v ní dějiny Irska a upozornil na okolnosti (rozsáhlé úplatky), za nichž anglická vláda docílila v roce 1800 převahy v irském parlamentu. „Hlavní činnost O'Connellova v celé této době bylo ustavičné shromažd'ováni (které tam zákon nezakazuje) národu irského, schüzka stíhala schůzku, a tak vzrüstalo uvédomění potřeb svých i síly, po rozličných městech vlasti své zakládal v národním duchu vedené noviny a časopisy, aby působily na míněni lidu a připravovaly jej lepším vzděláním ku politické dospělosti. Podněcuje řeči i skutkem lid, aby dbal o samostatnost svou a lepši práva, uměl jej zároven vzdržovati od všelikého násilného povstání, ačkoli utiskování od anglické vlády k němu popuzovala. " 


\section{Národní noviny a revoluční rok 1848}

Revoluce roku 1848 zasáhla téměř celou Evropu, nevyhnula se přirozeně ani habsburské monarchii a českým zemím, které byly její součástí. Změny se promítly do všech sfér života - politických, sociálních, hospodářských i mentálních. Formulovány byly základní občanské požadavky. Živá byla především otázka česko-německá a postoj k velkoněmeckým snahám.

Význam tisku za revoluce mimořádně vzrostl poté, co byla císařským patentem dne 15 . března 1848 zrušena cenzura. Karel Havlíček se tehdy ptal: ,Kterak budeme uživati svobody, zvyklí jsouce na uzdu cenzurní? Celá Evropa hledi nyní na nás, okážeme-li se hodni svobody, nebudeme-li uživati svobody nerozumně ke zlému. Dokažme, že jsme byli již dávno pro duševní samostatnost dozráli: držme se vážně, zmužile, aby snad zlomyslní nepřátelé svobod, kterých jest nyní veliký počet, neukazovali s ousměškem zlostným na nás, že nejsme hodni svobody. “

Za nových poměrů Havlíček opustil redakci Pražských novin a rozhodl se pro vlastní nezávislé noviny - od 5. dubna 1848 začaly vycházet Národní noviny. Svůj první text v nich uzavřel výzvou: „,Bratři! Směle kupředu! “

Havlíček věřil i v tak vypjaté době v rozum a potřebu vzdělání, odmítal střety, plédoval pro „,revoluce $v$ hlavách, ne zbraněmi " a rovnoprávnost národa, vyzdvihoval ty, „,kteři ctí zásadu, že všechna moc pocházi od národa“. Prostředkem k tomu měla být osobní - občanská - bezúhonnost a zodpovědnost: „, $O$ každém, který se vám v politických a veřejných záležitostech za rádce nabizi, hled'te se vždy napřed strany jeho domácího i privátního života presvědčiti, je-li zachovalý muž. Kdo je ničema, ... ten také jistě nemíchá se do politiky z poctivých oumyslì. "

Porážka svatodušního povstání v Praze v červnu, kapitulace Prahy a následující vyšetřování znamenaly i zatýkání. Mezi zatčenými byl kvưli svým článkům začátkem července i Karel Havlíček. Z vězení na Pražském hradě se dostal díky tomu, že byl zvolen poslancem do ústavodárného říšského sněmu, který zasedal ve Vídni od 22. července a k němuž Havlíček upínal velké naděje.

O sněmu Havlíček psal velmi kriticky do Národních novin. Jako např́klad 3. srpna 1848: „,Bohužel trpí posavad náš prvni řišský sněm nedostatky každého počátku veřejného oustniho jednání: veliký počet sněmovníkủ posavád se nabažiti nemohl do sytosti toho blaha, aby mluvili, a proto se bohužel tuze mnoho mluví jen proto, aby se mluvilo a aby se snad nezdálo, že některý pan deputovaný němý jest. Při největším počtu rečí nedá se skutečně žádná jiná príčina nalézt, proč by držány byly. “

Ŕíjnové události 1848 ve Vídni byly natolik krvavé, že mnozí poslanci, včetně českých, tedy i Havlíčka, z metropole nakvap odjeli. Sněm opět zasedal od 22. listopadu v Kroměříži. Havlíček ale předčasně opustil poslanecké lavice těsně před Vánocemi 1848. Jeho jednání ovšem v Národních novinách nadále komentoval. Když 7. března 1849 bylo zasedání sněmu násilně ukončeno a státní mocí byla zemi vnucena nová ústava, byl Havlíček událostmi v první chvíli doslova omráčen. Svým článkem Výklad oktrojované ústavy od 4. března 1849 se dostal do ostrého



Obr. 6. První číslo Havlíčkových Národních novin ze dne 5. dubna 1848. Foto: Knihovna Národního muzea.

konfliktu s úředními místy. Byl postaven před porotní soud, který jej v dubnu 1849 osvobodil. Konflikty se ale prohlubovaly, protože Havlíček dokázal vládě připomínat její nedodržené sliby, její vlastní proklamace. Začátkem roku 1850 pak byly jeho Národni noviny zastaveny. Havlíčkovi se nepodařilo přes veškerou snahu dosáhnout toho, v čem byl úspěšný dřív - prosadit znovuvydávání svého listu.

\section{Slovan a Havlíčkův závěr života}

Havlíček svou novinářskou prací získal respekt i ve Vídni. Proč by jinak chtěli jeho Národní noviny, když je úředně zastavili, ,koupit“? Havlíček se koupit nenechal a sliboval, až bude znovu panovat svoboda slova, že okolnosti tohoto jednání s vídeňskými úřady zveřejní. To už mu dopřáno nebylo. Našel útočiště v Kutné Hoře, kde nepanoval stav obležení jako v Praze, a zde vydával další svůj list - Slovan.

Havlíček hned v prvním čísle Slovanu ze dne 8 . května 1850 formuloval své krédo: „, Nemohla by zajisté malá hrstka vládychtivých utiskovati ku svému prospěchu celý národ, kdyby tento, jsa náležitě vzdělán, rozuměl všem svým záležitostem a svou vůli náležitě projeviti a provésti uměl. Úkolem svobody tisku jest tedy povýšiti poznenáhlu celý národ, neb alespoň největši část jeho k takovému vzdělání, a jen tenkrát můžeme sobě dělati naději na opravdivou a jistou svobodu. Třeba se i národu podařilo náhodou skrze revoluci svrhnouti se šije své jařmo absolutni vlády, jestli zároven̆ neni větší část jeho vzdělána, v brzkém času zase jiní pod jinými 

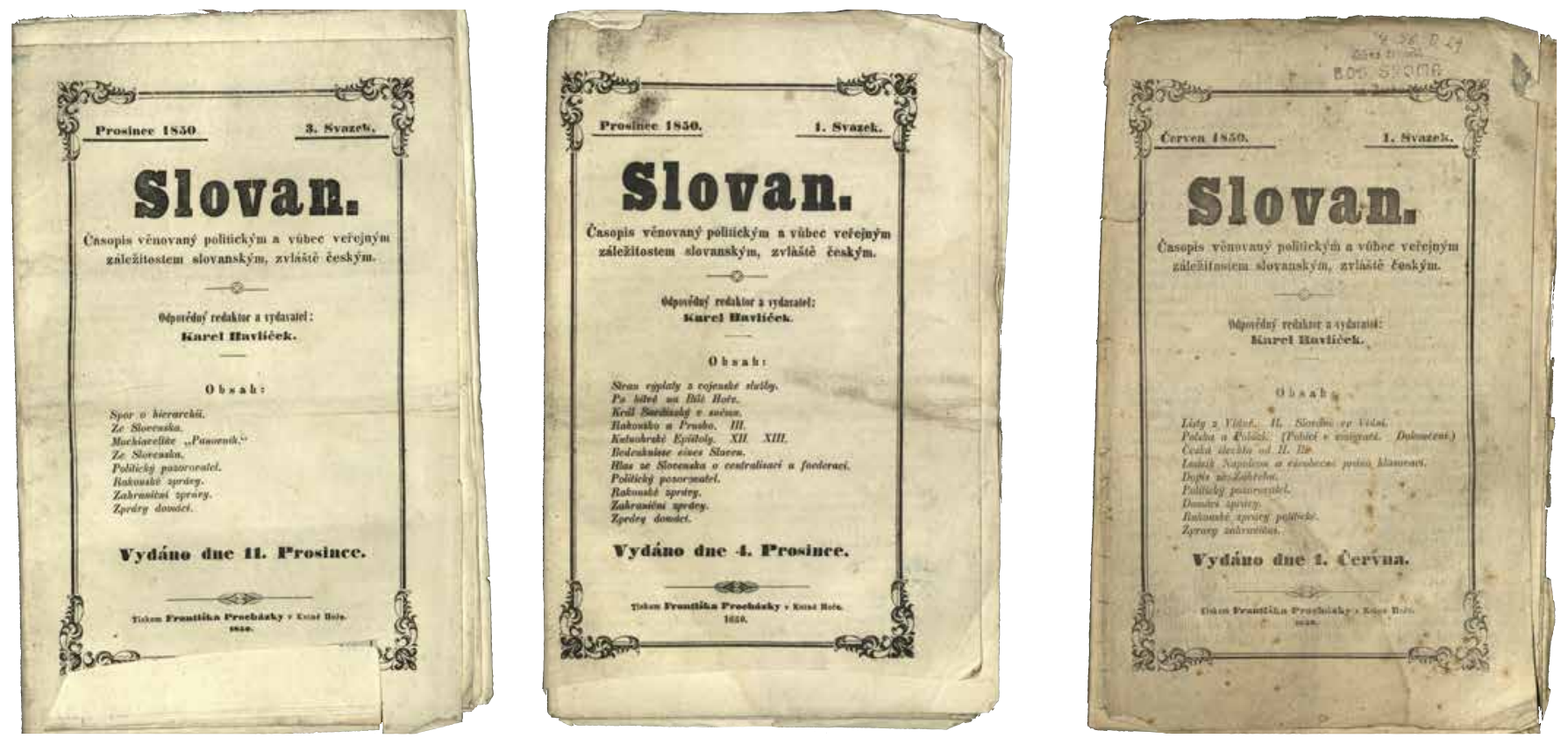

Obr. 7. Tři čísla Havlíčkova Slovana z roku 1850, který vycházel v Kutné Hoře. Foto: Knihovna Národního muzea.

záminkami dovedou se zmocniti libovolně a protizákonní vlády nad národem, jako toho právě za našich časủ leckde príklady vidíme. “

Hned od počátku byl Slovan tvrdě stíhaný úředními zákroky a konfiskacemi. Bylo také brzy zakázáno jeho šíření do Haliče, Krakova, Bukoviny, Uher a samozřjejmě nesměl do Prahy, stejně jako Havlíček. Docházelo až k paradoxním situacím, že v Praze nebyl Slovan k dispozici ani tomu novináři, který měl jeho názory rozporovat. Byl jím Václav Jaromír Picek, jemuž bylo nakonec úředně zakázáno se o Havlíčkovi vůbec zmiňovat, když se ukázalo, jak bezzubé jsou jeho repliky ve srovnání s Havlíčkovými texty.

V této komplikované situaci se Havlíček rozhodl pro důležitý krok. Uvědomoval si, jak krátký je život denního tisku a publikovaných stanovisek v nich. Po obdržení dvou úředních výstrah vydávání Slovanu v srpnu 1851 sám zastavil. Tehdy připravil knižní soubory ze svých textů z Národních novin (Duch Národních novin) a ze Slovanu (Epištoly kutnohorské). Přestože byly tyto knihy po svém vydání v podstatě bezprostředně konfiskovány, dokázal je $\mathrm{v}$ jisté míře přece jenom distribuovat. V mnoha rodinách se pak po dlouhá léta staly až jakousi relikvií. Kutnohorskou tečkou v Havlíčkově novinařině bylo zasedání porotního soudu v listopadu 1851, jenž ho díky skvěle vystavěné osobní obhajobě osvobodil. O měsíc později, 16. prosince, byl z Německého Brodu odvezen do tyrolského Brixenu.

Podrobnosti jeho cesty známe z Havlíčkových Tyrolských elegií, ale také z výtvarného zpracování, díky němuž byl i konstruován obraz Havlíčka - mučedníka. Dnešní návštěvníci Brixenu - turisticky atraktivního místa v nádherné krajině - zas mohou nabývat dojmu, že Havlíčkův pobyt zde musel být báječnou, a to hned několikaletou dovolenou, a to ještě rakouskými úřady placenou! Nic není tak vzdáleno pravdě. Ani obraz Havlíčka jako mučedníka, ani Havlíčka jako rekreanta.

Havlíčka a odezvy jeho textů u veřejnosti se úrrady obávaly. S novináŕi radikálně demokratického směru probíhaly či se chystaly v této době soudy a ty svůj ortel vyřkly - tresty smrti, dlouholetá vězení atd. Havlíček dokázal jít na hranu možností, ale k odsouzení, i pro jeho schopnosti svá stanoviska nenapadnutelně formulovat, u něj nedošlo. Dva porotní soudy, jeden v Praze, druhý v Kutné Hoře, jej osvobodily.

Úřady proto u něj volily cestu mimosoudního rozhodnutí - internovaly jej. O místě internace se rozhodovalo na poslední chvíli a na nejvyšších místech ve Vídni. Brixen pro Havlíčka znamenal odloučení od rodiny, od přátel, od kvasu každodenní práce. Uvrhl jej do beznaděje. Byl sledován, byly u něj prováděny domovní prohlídky, pod dohledem úřadů byl jak on, tak všichni, s nimiž se stýkal, i jeho korespondence. Nevěděl, protože nebyl odsouzen, jak dlouho tam bude muset zůstat. Pobyt, který úřady povolily jeho ženě Julii a dceři Zdence, sice Havlíčkovi pochopitelně ulehčil, ale jeho životní perspektivu zásadně neřešil. ,, Teletina jako mandle, vína taky dost, jakou čekáš, duše moje, ještě blaženost? “, to byl trpký Havlíčkův povzdech z této doby. Vnímal také jako velkou křivdu, když po císařově sňatku v dubnu 1854 byli mnozí soudy odsouzení vězni propouštěni, zatímco jeho, jako neodsouzeného, se amnestie netýkala. Žádosti, které po předešlém jednání švagra Františka Jaroše na úřadech ve Vídni sepsal a podal, procházely zdlouhavě celým byrokratickým aparátem. Nejdř́ve ztroskotala na zamítavém stanovisku úřadů v Praze, které se Havlíčka pořád bály, ta další, podaná v lednu 1855, nakonec byla úspěšná, ale Havlíček se musel zavázat, že se už nebude věnovat žurnalistické práci. To byla pro něj obět' nejvyšší. A to ještě nevěděl, že vlastně marná.

Návrat domů v roce 1855 mu mnoho radosti nepřinesl dozvídá se zde o smrti manželky Julie a zjišt'uje, že mnoho jeho přátel se s ním odmítá stýkat. K tomu se zhoršoval jeho zdravotní stav způsobený tuberkulózou, který ho přivedl k pobytu v lázních Šternberk u Smečna. Havlíčkův závěr života byl neodvratitelný. Ve snaze ulevit si od bolestí se předávkoval morfiem, v důsledku čehož upadl do bezvědomí. Zemřel krátce po převozu do Prahy dne 29. července 1856. 


\section{Rodiče, bratři, sestra, manželka a dcera Zdenka}

Otec Karla, Matěj Havlíček (1792-1844), se narodil v kupecké rodině. Vyučil se obchodníkem v Německém Brodě (výuční list získal v roce 1813), praxi pak absolvoval v Praze. Rozhodl se založit obchod v Borové, kde takový obchod zatím nebyl. Úřední povolení ke zřízení obchodu získal v roce 1817. Brzy nato se oženil (1818) s Josefou Dvoŕákovou (1791-1884).

Matěj Havlíček byl schopným obchodníkem a dětmi byla požehnána i jeho rodina. Jako první se narodil 21. dubna 1819 Filip, ten ale hned dva dny po narození zemřel. O dva a půl roku později, 31. ř́jna 1821, se narodil druhý syn, jehož místní farář Jan Brůžek pokřtil jménem Karel Boromejský Oldřich, to byl „nášc Karel Havlíček. Mladším Havlíčkovým bratrem byl František (1823-1912), Josef (1830-1889) a nejmladší byla Johana Nepomucena (1832-1913).

„Co jsem poznal srdce tvé, Juliánko moje, zase vidím hvězdičku, ale ta je tvoje, " to jsou známé, často citované verše Karla Havlíčka, které věnoval své pozdější manželce Julii Sýkorové.

Dne 27. prosince 1847 Havlíček avizoval mamince budoucí sňatek, ke kterému došlo v březnu 1848: „A strany té holky, kterou si vezmu, neměj taky pražádnou starost, budeš vidět, až ji poznáš, že je hodná a hospodářská a že má dobré vychování."

Julie byla dcerou Františka Sýkory, lesního vrchnostenského úředníka ve Svojšicích, a Anny, rozené Sládečkové, která také pocházela $\mathrm{z}$ rodiny lesního vrchnostenského úředníka.

Julie byla zaměstnána jako modistka v pražském salónu, který jí kromě znalosti řemesla nabídl i společenskou prestiž,

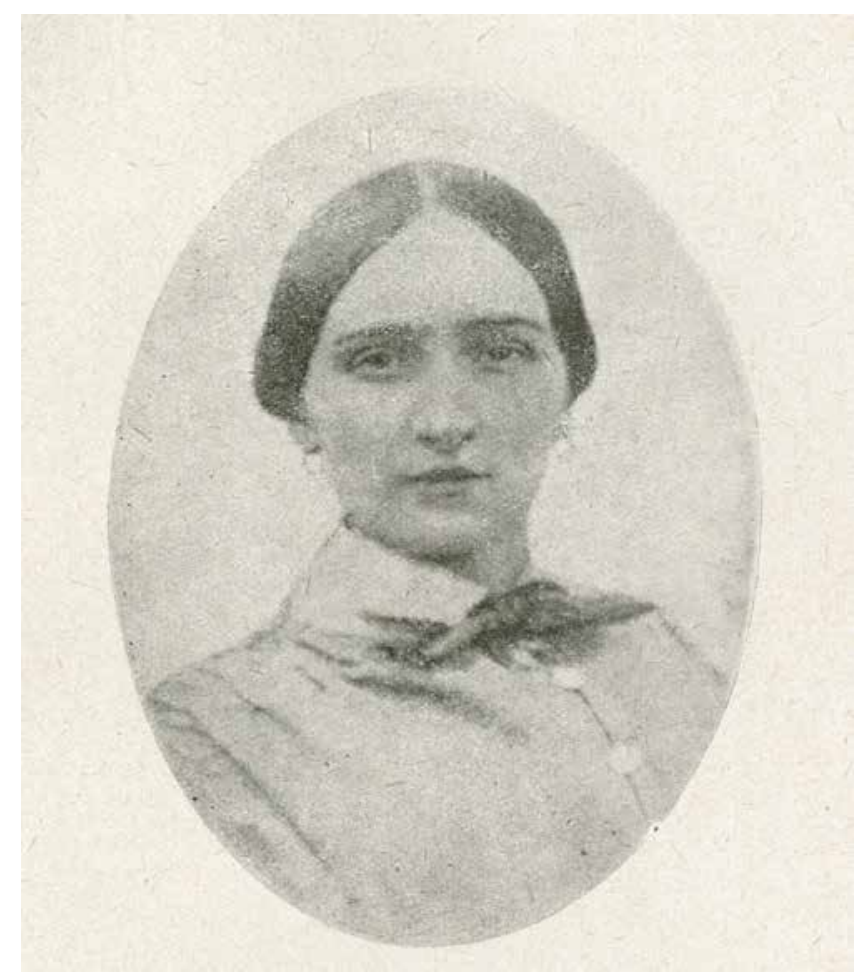

Obr. 8. Julie Havlíčková (1826-1855), manželka Karla Havlíčka. Foto: Národní muzeum.

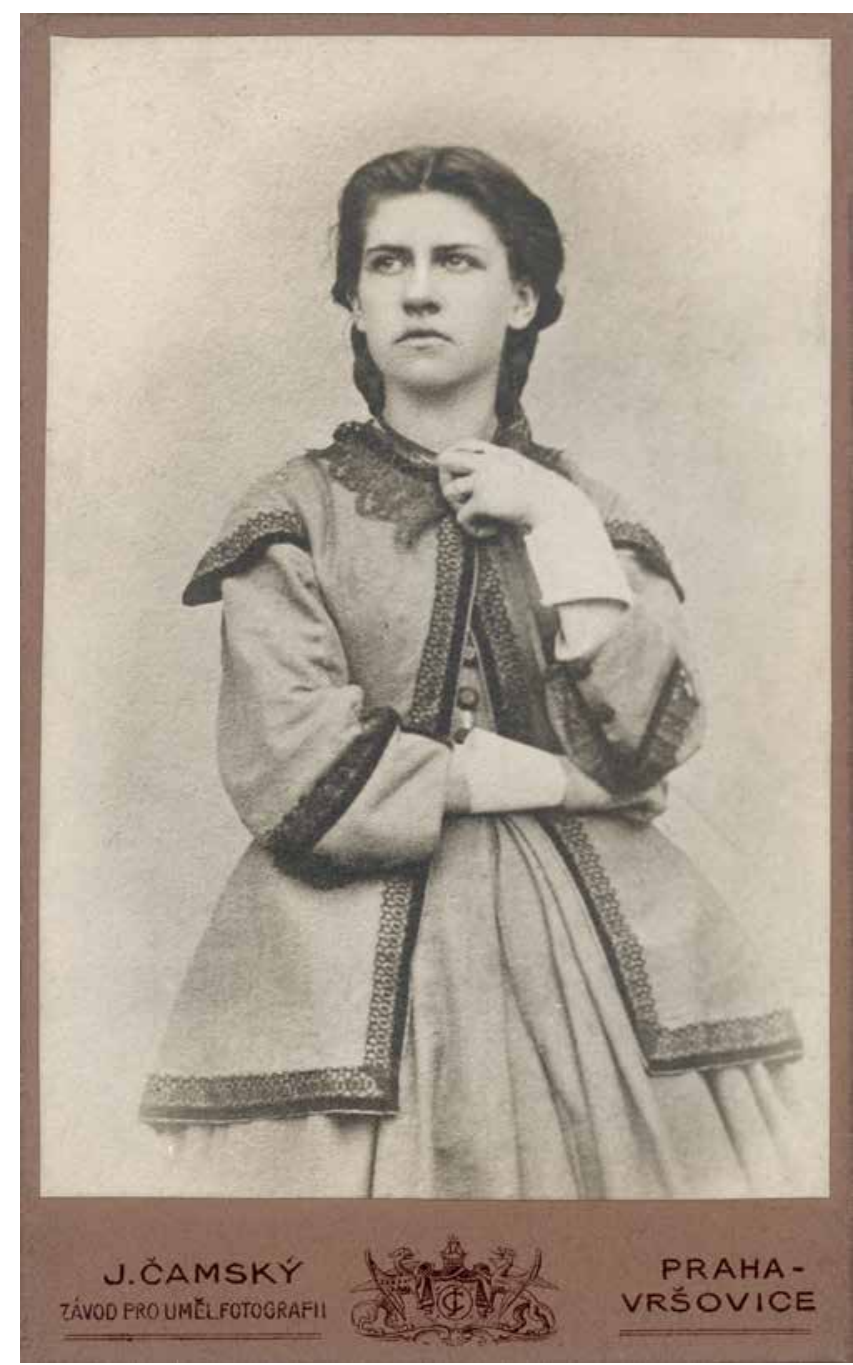

Obr. 9. Fotografie Zdenky Havlíčkové (1848-1872), dcery Karla Havlíčka. LA PNP, fotoarchiv.

kam docházeli mnozí mladí lidé, včetně Havlíčka. Po sňatku Julie vplula do Havlíčkovy rodiny, přilnula, jak vypovídá byt' nečetná dochovaná korespondence, k Havlíčkově matce. S radostí přijala její nabídku, aby jí stejně jako její ostatní děti mohla tykat. To nebyla tehdy, ale ani ještě dlouho poté, samozřjejmá věc.

Havlíčkovi se dne 23. prosince 1848 v Praze narodila dcera. Pyšně se do Německého Brodu chlubil: ,,Zrovna ted’ v 1 hodinu s poledne narodila se nám št'astně holka, zdravá jako ryba a silná. Julie neměla dlouhý porod a byl co možná lehký. Je zdravá jakoby nic. " Julie psala mamince až později a s úlevou: „Mnohokrát jsem si již spomněla na Tvé slova, že bude mít holku taky rád, jest tomu vskutku tak, ani bych si to byla nemyslila. "

Soužití manželů Havlíčkových ovlivňovalo Havlíčkovo pracovní vytížení, následně úřední perzekuce a internace v Brixenu. Komplikovaly jej ale i zdravotní problémy, dlouhodobě se projevovaly u Julie, která nakonec podlehla nemoci ve svých sotva 29 letech v dubnu 1855. V Praze se už ani nedočkala manželova návratu.

Život jediného Havlíčkova potomka, dcery Zdenky, ovlivnili v útlých letech nejen rodiče, ale také rodina její tety Adély Jarošové, kde Zdenka žila po smrti svých rodičů. 
Ovlivnila jej ale později zcela zásadně i snaha představitelů české vlastenecké společnosti prezentovat právě na ní a v péči o ni ideál národní výchovy. Byla vytržena z rodinného prostředí, vychovávána $\mathrm{v}$ dalších rodinách (Hanušovi, Braunerovi, Trojanovi, teprve konec života strávila u babičky v Německém Brodě), to vše, i snaha zasahovat do jejího citového života, mladou dívku poznamenalo. Zdravotní rodinná zátěž - tuberkulóza - ukončila život „dcery národa“ dne 20. záŕí 1872.

\section{Karel Havlíček a představitelé českého národního života}

Sebevědomí, pohotovost a mimořádné vyjadřovací schopnosti se u Havlíčka snoubily se soustavností, pracovitostí a pílí. Sám se v deníkovém záznamu z 13. ledna 1842 dovolával v tomto směru Boží pomoci: „,Bože, dej mi, abych byl pilným, aby ze mne někdy měli Češi radost. " Sám ale dovedl přiznat, že byl od dětství „hranatá“", samorostlá a vzdorná povaha, že byl svéhlavý, až zarputilý chlapec, který se nepodroboval snadno. I tyto rysy povahy mu zůstaly po celý život.

Během svého novinářského působení vystupoval proti př́zemnímu vlastenčení, polemizoval nejen s Josefem Kajetánem Tylem, ale i s Jakubem Malým. Dostal se do sporu i se slovenským ,separatismem“. Spor stíhal spor a polemika polemiku. V umění polemizovat se Havlíček zdokonaloval, co se týče vervy, vtipu i důraznosti, stejně jako sarkasmu. Později stíhal rakouskou vládu a čelil i hlasům z německých a polských periodik, do konfliktů se dostával s českými radikálními demokraty i s konzervativním táborem. Pochvaloval si dokonce, že tolik nepřátel nikdy neměl, a soudil, že čím více má nepřátel, tím více je mu prokazováno cti.

Dokázal ovšem respektovat autority, které jej přesvědčily svými argumenty, životními postoji i charakterem. Hned v dětství to byl borovský farář Jan Brůžek. Po příchodu do Prahy pak především František Palacký, osobnost, která ovlivnila českou společnost v mnoha směrech. Havlíčka doporučil na místo redaktora Pražských novin - a tím mu pomohl splnit jeho ambice. Povzbuzoval jej svými dopisy i do Brixenu.

V revolučním období 1848 spojovaly Františka Palackého a Karla Havlíčka i politické názory - liberální postoje i austroslavismus. V tom souzněli s dalším politikem, jehož hvězda tehdy začala stoupat, a to s Františkem Ladislavem Riegrem. Ten Havlíčka důkladně informoval o počátcích revolučního hnutí v Itálii, kde právě pobýval, spolu pak působili jako poslanci ve Vídni. Dne 30. ř́ijna 1879 vzpomínal F. L. Rieger na říšské radě: „, Tehdy se stalo, že jsem se dostal na proskripční listinu a že mne hledali dělníci v mém bytě, a kdybych nebyl býval náhodou varován přitelem Havličkem, mohl jsem sdileti osud s Latourem ", tehdy davem lynčovaným rakouským ministrem. Havlíček ještě z Brixenu Riegrovi gratuloval $\mathrm{k}$ sňatku s Marií Palackou v srpnu 1853: „Kdo chce hezkou ženu mít, musí pro ni do Čech jit, / jsout' veselé jak mladé kočičky / Ličko bílé jako sníh, husté brvy na očich / zrak se blyští jako dvě hvězdičky [...]“

Nebyli to jen reprezentanti české politiky, jejichž dílo Havlíček respektoval, byla to i Božena Němcová, která do Havlíčkem redigovaných novin přispívala, stejně tak jako její manžel Jose f Němec. Pro Josefa Němce pak byl vztah k Havlíčkovi i v době jeho vlastního nuceného působení mimo české země i jakýmsi „poznávacím znamením“, např́klad při rozhodování, komu při seznamování s dosud neznámými lidmi věřit.

Havlíček si díla Boženy Němcové cenil, což je zřejmé i z toho mála dopisů, které se zachovaly. S ohledem

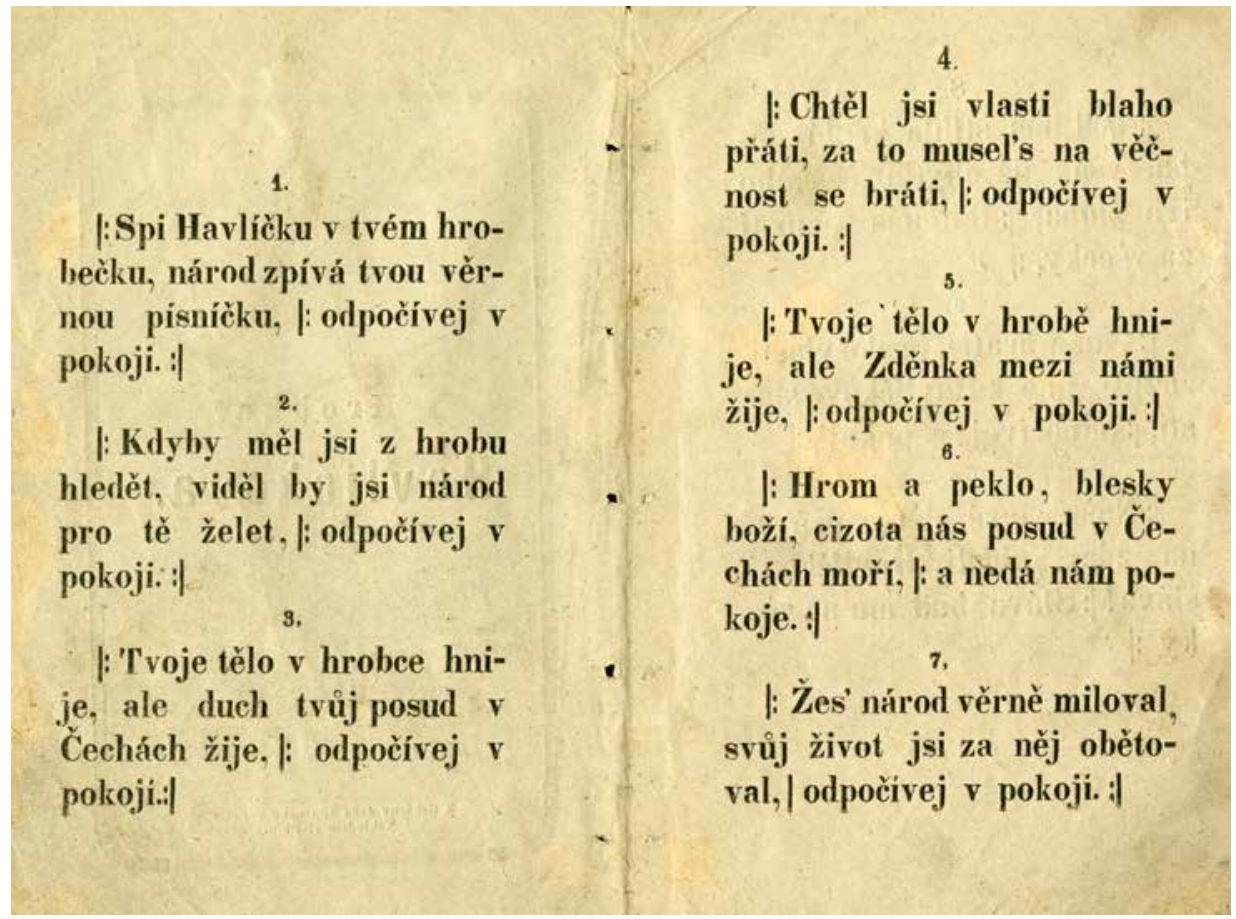

Obr. 10. Kramářská píseň Hrobka Havlíčkova pravděpodobně od českého písničkáře Františka Haise vznikla krátce po Havlíčkově smrti a dosáhla ve společnosti mimořádného ohlasu. Foto: Knihovna Národního muzea. 
na panující cenzurní poměry ovšem nemohl vše, co mu poslala, otisknout, proto se omlouval v dopise z prosince 1846: „Až Vy budete mou cenzorkou (kýž by to pánbůh dal!) aneb až bude policie rakouská tak milostivá jako Vy, pak ano, co žádati budete. Ale ted' nemožná! Proti vládě může se více psát, protože se toho nikdo neujme, ale proti kněžím ne, nebot'se sesypou na člověka jako hnizdo vosí! “

\section{Havlíčkův mýtus}

Druhý život Karla Havlíčka začal bezprostředně po jeho smrti - už samotným pohřbem dne 1. srpna 1856, který se stal národní manifestací. Účastnili se jej lidé nejen z Prahy, ale i ze vzdálených míst. Doprovázeli rakev s Havlíčkovými ostatky z domu smutku nejen „,k bráně“, jak bylo tehdy obvyklé, ale až na Olšanský hřbitov, kde byl uložen k poslednímu odpočinku. Účastníci pohřbu byli úředně sledováni. Úřady chtěly situaci monitorovat, ale nechtěly průběh pohřbu tak zásadně ovlivnit. Početná účast veřejnosti i odezva pohřbu mezi obyvatelstvem nakonec ale vedly nejen ke stíhání aktivních účastníků (např́iklad Josefa Němce), ale i prý „liknavého“ postoje tehdejšího vysoce postaveného úředníka v Praze Filipa Webera.

Tehdy se začaly objevovaly zprávy o tom, že byl Havlíček úruedními místy otráven. I příběh o vavřínovém věnci, který měl být položen na jeho rakev Boženou Němcovou, se stal mýtem, přestože tato událost podle úředních hlášení proběhla jinak.

Proč se tedy vracet ke Karlu Havlíčkovi?

Havlíček byl pohotový novinář a díky tomu rychle pronikal k podstatě věcí. Dokázal vládě připomínat její vlastní sliby. Jeho politické přesvědčení vycházelo z kritiky církevní hierarchie, federalismu a z českého národního liberalismu a občanského programu.

Svou pohotovostí a důsledností také dráždil. A dráždil také vtipem, někdy až sžíravým. Neústupnost a neúplatnost jej provázela po celý, byt' krátký, život. Zemřel v 35 letech a přestal veřejně působit, když mu nebylo ještě třicet. $Z$ člověka, který svým aktivním životem a celým dílem kritizoval sentimentalismus, sladkobolnost, se stal „mučedník“, trpitel.

,Jindy umirali mužové pro čest, pro blaho svého národa, my však z téže př́činy budeme žíti a pracovati. " (Pražské noviny, 18. 1. 1846)

\section{| Magdaléna Pokorná} Historický ústav AV ČR, v. v. i.

Prosecká 809/76

19000 Praha 9 